(C) The Author 2002

\title{
The argument for increasing selenium intake
}

\author{
Margaret P. Rayman \\ Centre for Nutrition and Food Safety, School of Biomedical and Life Sciences, University of Surrey, Guildford GU2 7XH, UK
}

\begin{abstract}
The essential trace mineral, Se, is of fundamental importance to human health. As a constituent of selenoproteins it plays both structural and enzymic roles, in the latter context being best known as an antioxidant and catalyst for the production of active thyroid hormone. While Se-deficiency diseases have been recognised for some time, evidence is mounting that less-overt deficiency can also cause adverse health effects and furthermore, that supra-nutritional levels of Se may give additional protection from disease. In the context of these effects, low or diminishing Se status in some parts of the world, notably in some European countries such as the UK, is giving cause for concern. While deficiency has an adverse effect on immunocompetence, Se supplementation appears to enhance the immune response. Se appears to be a key nutrient in counteracting certain viral infections; thus, in a Se-deficient host the benign coxsackie virus becomes virulent, causing heart damage, the influenza virus causes more serious lung pathology and HIV infection progresses more rapidly to AIDS. Long recognised as essential for successful animal reproduction, $\mathrm{Se}$ is required for human sperm maturation and sperm motility and may reduce the risk of miscarriage. Deficiency has been linked to adverse mood states. Findings have been equivocal in linking Se to cardiovascular disease risk, although other conditions involving oxidative stress and inflammation have shown some association with Se status. There is growing evidence that higher $\mathrm{Se}$ intakes are associated with reduced cancer risk. While persuasive evidence already exists to suggest that additional Se would be beneficial in some health conditions, results from intervention trials underway or planned have the potential to reinforce or refute the argument for increasing Se intake.
\end{abstract}

Selenium: Selenium intake: Supra-nutritional intakes: Selenium status: Human health

It is hard to overestimate the importance of Se to biological systems. Its crucial role is underlined by the fact that it is the only trace element to be specified in the genetic code. It is specified as selenocysteine, now recognised as the 21 st amino acid, as it has its own codon and selenocysteinespecific biosynthetic and insertion machinery (Gladyshev, 2001a). In the presence of a downstream stem-loop structure, the UGA codon in mRNA, instead of behaving as a stop codon, specifies the insertion of a selenocysteine moeity in protein synthesis to give a selenoprotein. Se, as selenocysteine in proteins, scores over its analogue, $S$, in existing as an anion (selenolate) at biological $\mathrm{pH}$ (acid dissociation constants: selenocysteine $5 \cdot 2$, cysteine 8.5 ; Stryer 1995; Stadtman, 1996). This property enables it to carry out biological redox reactions. Its additional ability as a metalloid to both give and accept electrons, makes it an ideal catalytic centre.
About fourteen mammalian selenoproteins have been characterised to date (Gladyshev, 2001a). A number of these selenoproteins have been identified as having enzymic (catalytic) redox activity, although structural and transport functions have also been recognised (Ursini et al. 1999; Hill \& Burk, 2001). Some known selenoproteins and their functions are listed in Table 1, which demonstrates the fundamental nature and role of the selenoproteins.

In this context, it is not surprising that Se adequacy is crucial to human and animal health (Rayman, 2000). While Se-deficiency diseases have been recognised for some time, evidence is now mounting that less-overt deficiency may also cause adverse health effects and, furthermore, that supra-nutritional levels of Se may give additional protection from some diseases. Low or diminishing Se status in some parts of the world, notably in some European countries of which the UK is one, is thus giving cause for concern

\footnotetext{
Abbreviations: GPx, glutathione peroxidase; HCC, hepatocellular carcinoma; NPC, Nutritional Prevention of Cancer; PRECISE, Prevention of Cancer by Intervention with Se.

Corresponding author: Dr M. P. Rayman, fax +44 1483686481 , email m.rayman@surrey.ac.uk
} 
Table 1. Known selenoproteins that carry out the nutritional functions of selenium

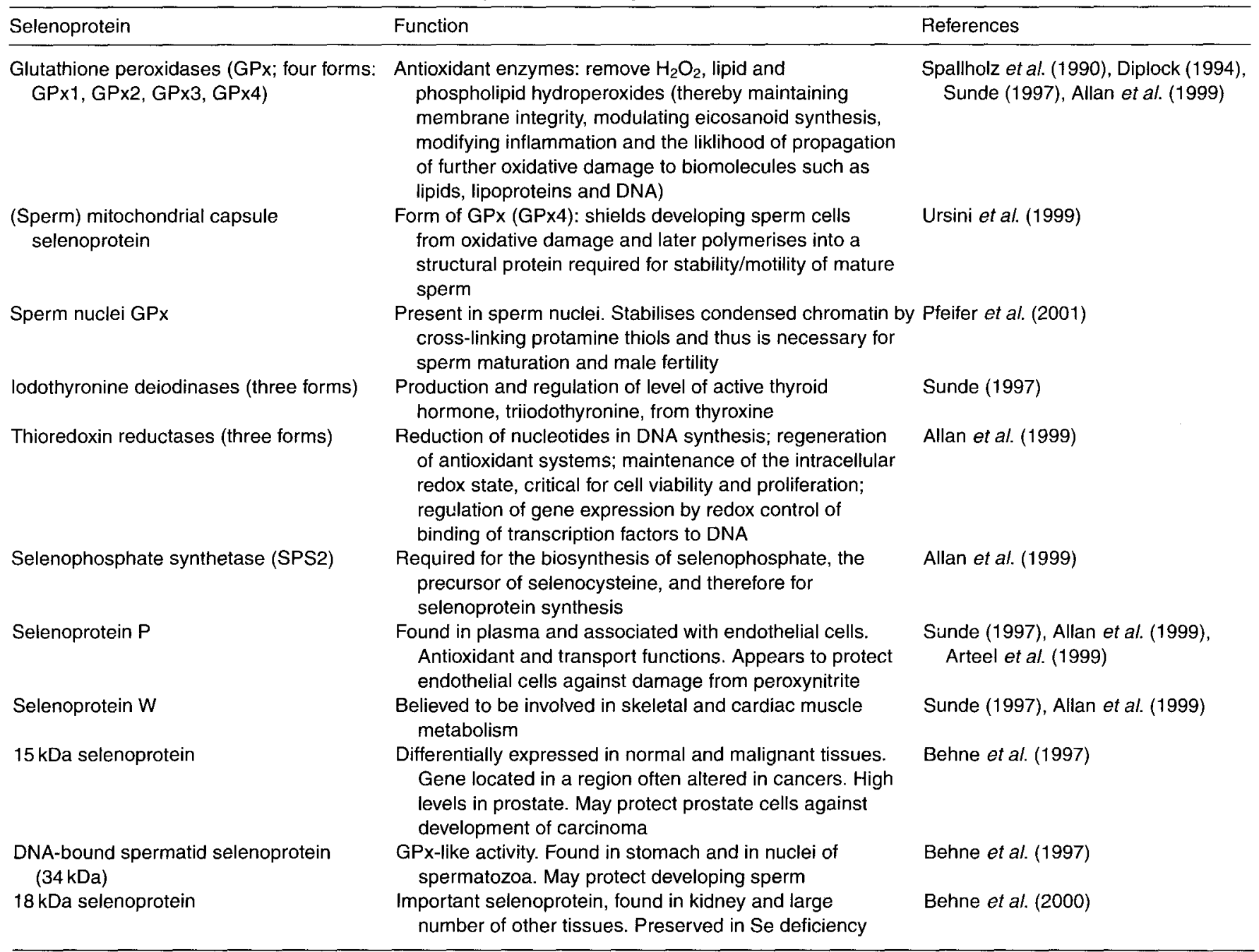

(Rayman, 2000). Combs (2001) estimates that the total number of Se-deficient individuals (as defined by submaximal selenoenzyme activity) is likely to be in the range of 500-1000 million.

Arguments for increasing Se intake are based on three premises: Se deficiency, even if marginal, may leave an individual less than optimally protected against a number of adverse health conditions; Se intakes above those required to replete the glutathione peroxide (GPx) selenoenzymes appear to confer additional health benefits; Se intake and status is low or marginal in many countries. Evidence in support of these premises follows.

\section{Health effects of selenium deficiency: overt or marginal}

\section{Selenium-deficiency diseases}

Diseases associated with overt Se deficiency have been recognised for some time in parts of the world notable for their low soil Se. Keshan disease is a cardiomyopathy, frequently fatal, named after the area in the extreme north- east of China where it was endemic. Prophylactic administration of Se has greatly reduced the incidence of the condition (Reilly, 1996a). A number of cases of cardiomyopathy have also been reported in subjects on intravenous nutrition receiving inadequate $\mathrm{Se}$ in their infusion solutions (Reilly, 1996b). Kashin-Beck disease is an osteoarthropathy found in rural areas of China, Tibet and Siberia (Coppinger \& Diamond, 2001) associated with severe Se deficiency. Both conditions are believed to require cofactors which, in the case of Kashin-Beck disease, may be low I status or the presence of fulvic acids or mycotoxins in foods (Moreno-Reynes et al. 1998; Coppinger \& Diamond, 2001). In severely Se-deficient parts of China, Tibet and Eastern Siberia affected by these diseases there is a clear argument for increasing $\mathrm{Se}$ intake. However, in other countries widely understood to have low soil Se (e.g. New Zealand) there is no evidence of these conditions. This is because $S e$ intakes are in fact substantially higher (Duffield et al. 1999), there is wider availability of non-local and imported foods, and at least some of the cofactors are absent. 


\section{Health effects related to the role of selenium as antioxidant}

Cardiovascular disease. Findings have been equivocal in linking Se to cardiovascular disease risk. On theoretical grounds, the protective effect of Se against cardiovascular disease is supported by the ability of GPx to combat the oxidative modification of lipids and to reduce platelet aggregation (Nève, 1996). GPx4 has been shown to reduce hydroperoxides of phospholipids and cholesteryl esters associated with lipoproteins (Sattler et al. 1994), and may therefore reduce the accumulation of oxidised LDL in the artery wall. GPx is required for the metabolism of hydroperoxides produced in eicosanoid synthesis by the lipoxygenase and cyclo-oxygenase pathways (Spallholz et al. 1990). In Se deficiency a build up of these hydroperoxides inhibits the enzyme prostacyclin synthetase, which is responsible for the production of vasodilatory prostacyclin by the endothelium, but stimulates the production of thromboxane, which is associated with vasoconstriction and platelet aggregation (Nève, 1996). The balance is therefore tipped towards the pro-aggregatory state. In men with coronary artery disease platelet aggregability has been shown to be inversely related to Se status (Salonen et al. 1988; Nève, 1996).

Prospective epidemiological studies have had mixed findings. While Salonen et al. (1982) found a two- to threefold increase in cardiovascular morbidity and mortality for subjects with serum Se levels $<45 \mu \mathrm{g} / \mathrm{l}$ compared with subjects above that level at baseline, Virtamo's group (Virtamo et al. 1985) found no significant associations with Se levels above and below that cut-off point, except for stroke mortality. A study by Suadicani et al. (1992) showed that middle-aged and elderly Danish men with serum $\mathrm{Se}$ $<79 \mu \mathrm{g} / \mathrm{l} \mathrm{had}$ a significantly increased risk of IHD (adjusted relative risk 1.55 (95\% CI 1, 2.39)). However, about six other studies have not shown a clear association between cardiovascular risk and low Se, although these studies differ from the previously mentioned studies in having included few or no subjects with low Se status (Salvini et al. 1995; Nève, 1996). That a low Se status may be relevant was suggested by the findings of Kardinaal et al. (1997) in the ten-centre EURAMIC study, in which a significant inverse association between toenail Se levels and risk of myocardial infarction was shown only for Germany, the centre with the lowest Se status (odds ratio 0.62 (95\% Cl 0.42, 0.91)). Thus, the effect may only be apparent in populations of low Se status, lower than the levels present in the USA and a large part of Europe. The disparity between studies may also be explained to some extent by the status of other antioxidants such as vitamin $\mathrm{E}$, which may compensate for a deficiency in Se in protection against atherosclerosis (Kardinaal et al. 1997).

A further factor to be taken into consideration when assessing these studies is that atherosclerosis is an inflammatory state and will provoke the acute-phase response to an extent related to its severity. Being an acute-phase reactant (Nicol et al. 1998), some fall in plasma Se concentration might be expected in subjects suffering from atherosclerosis, even before the occurrence of an event.

Other oxidative stress conditions. Other conditions involving oxidative stress and inflammation have shown some association with Se status. Se behaves both as an antioxidant and an anti-inflammatory agent. This is because Se in its antioxidant role, notably as GPx, can: (1) reduce $\mathrm{H}_{2} \mathrm{O}_{2}$, lipid and phospholipid hydroperoxides, thereby dampening the propagation of free radicals and reactive oxygen species; (2) reduce hydroperoxide intermediates in the cyclo-oxygenase and lipoxygenase pathways, preventing the production of inflammatory prostaglandins and leukotrienes; (3) modulate the respiratory burst, by removal of $\mathrm{H}_{2} \mathrm{O}_{2}$ and superoxide (Spallholz et al. 1990).

Any condition associated with increased levels of oxidative stress or inflammation might be expected to be influenced by Se status. There is some evidence that this is the case in rheumatoid arthritis, pancreatitis, asthma and systemic inflammatory response syndrome.

In a case-control study nested within a Finnish cohort of 18709 men and women who had no arthritis at baseline, the adjusted relative risk between the highest and lowest tertiles of serum Se was 0.16 (for trend, $P=0.02$ ) for rheumatoid factor-negative arthritis. There was no association for rheumatoid factor-positive rheumatoid arthritis (Knekt et al. 2000). In a double-blind randomised controlled trial in a small group of patients with rheumatoid arthritis, supplementation with $200 \mu \mathrm{g} \mathrm{Se}$ as Se-enriched yeast for 3 months, gave a significant reduction in pain $(P<0.01)$ and joint involvement $(P<0.05$; Peretz et al. 1992). However, a later similar study by the same group found only an improvement in arm movements and health perception (Peretz et al. 2001). There is evidence for a protective effect of Se in pancreatitis, a condition associated with a high level of oxidative stress. At Manchester Royal Infirmary, Manchester, UK, administration of Se $(600 \mu \mathrm{g} / \mathrm{d})$ along with other antioxidants to patients with chronic and recurrent pancreatitis, significantly reduced pain and number of $d$ spent in hospital $(P<0.001$ and $P<0.05$ respectively; McCloy, 1998). Treatment has been revolutionised by obviating the need for surgery for pancreatic pain (McCloy, 1998). Se has also shown benefit in acute pancreatitis. In a small controlled trial carried out in Rostock in Germany intravenous administration of Se to patients suffering from acute necrotising pancreatitis reduced mortality from $89 \%$ in controls to $0 \%$ in the treatment group (Kuklinsky \& Schweder, 1996).

With regard to asthma, a protective relationship was found between dietary Se intake and asthma in adults in a large population-based case-control study in London (odds ratio per quintile increase $0.84 ; P=0.002$; Shaheen et al. 2001). A suggestion of reduced risk was found in a nested case-control study of 7217 Finnish men and women (relative risk 0.64 (95\% CI 0.31, 1.31)) between highest and lowest quartiles of serum Se (Knekt 2002). In a small nested case-control study, current wheeze among New Zealand children was found to be more common in those with low levels of Se in serum samples collected 8 years previously (odds ratio 3.1; Shaw et al. 1994). Another small study in intrinsic asthmatics showed significant clinical improvement $(P=0.042)$ on daily supplementation with $\mathrm{Se}$ at $100 \mu \mathrm{g} / \mathrm{d}$ as $\mathrm{Na}_{2} \mathrm{SeO}_{3}$ (Hasselmark et al. 1993).

Although only relevant to extremely ill patients in the intensive treatment unit, some remarkable results were achieved in a trial of Se supplementation in systemic inflam- 
matory response syndrome (Angstwurm et al. 1999). In a controlled randomised prospective open-label pilot study on forty-two patients with Acute Physiology and Chronic Health Evaluation II scores (a point score based on initial values of twelve routine physiological measurements, age and previous health status, to provide a general measure of severity of disease on admission to hospital; Knaus et al. 1985) of fifteen points on the day of admission, those given substantial doses of $\mathrm{Na}_{2} \mathrm{SeO}_{3}$ (maximum dose $535 \mu \mathrm{g} / \mathrm{d}$ ) had significantly lower Acute Physiology and Chronic Health Evaluation III scores (which relate to follow-up during treatment and predict hospital mortality risk for critically ill hospitalised adults; Knaus et al. 1991) on days 7 and 14, ( $P=0.018$ and $P=0.045$ respectively), lower mortality $(33.5 \% v .52 \%)$ and there was a significant reduction in the number of patients requiring haemodialysis as a result of acute renal failure $(P=0 \cdot 035)$.

\section{Effects on the immune system}

While deficiency has an adverse effect on immunocompetence, Se supplementation appears to enhance the immune response. In Se deficiency both cell-mediated immunity and B-cell function can be impaired (Spallholz et al. 1990). Thus, the delayed-type hypersensitivity skin reaction is significantly suppressed $(P<0.01)$ in Se-deficient rats (Kukreja \& Khan, 1998), while vaccination of Se-deficient animals is not followed by effective immunisation, showing the inability to mount an antibody response (Sanders, 1984). Furthermore, neutrophils and macrophages from Sedeficient animals show failure to kill ingested Candida yeasts (Turner \& Finch, 1991).

In contrast, supplementation with $\mathrm{Se}$, even in 'Se-replete' individuals, has been shown to have marked immunostimulant effects, including an enhancement of proliferation of activated T-cells, otherwise known as clonal expansion (Kiremidjian-Schumacher et al. 1994). Lymphocytes from subjects supplemented with $\mathrm{Se}$ (as $\mathrm{Na}_{2} \mathrm{SeO}_{3}$ ) at $200 \mu \mathrm{g} / \mathrm{d}$, showed an enhanced response to antigen stimulation and an increased ability to develop into cytotoxic lymphocytes and destroy tumour cells. Natural killer cell activity was also increased. The supplementation regimen resulted in a $118 \%$ increase in cytotoxic lymphocyte-mediated tumour cytotoxicity and an $82 \%$ increase in natural killer cell activity as compared with baseline values (Kiremidjian-Schumacher et al. 1994).

The mechanism appears to be closely related to the ability of $\mathrm{Se}$ to up-regulate the expression of receptors for the growth regulatory cytokine interleukin 2 on the surface of activated lymphocytes and natural killer cells, thereby facilitating their interaction with interleukin 2 . This interaction is crucial for clonal expansion and differentiation into cytotoxic T-cells. Results of this study indicate that even at so-called replete levels of plasma Se produced by normal dietary intake in the USA, i.e. $120-134 \mu \mathrm{g} / 1$, supplementation with $200 \mu \mathrm{g} / \mathrm{d}$ Se has considerable immunoenhancing effects (Kiremidjian-Schumacher et al. 1994). These effects have been demonstrated by the same research group in patients undergoing therapy for head and neck cancer (Kiremidjian-Schumacher et al. 2000).
Se appears to be able to reverse the age-related decline in immune response in the elderly. In a group of twenty-two institutionalised elderly subjects supplemented with $100 \mu \mathrm{g}$ Se-enriched yeast/d or placebo for 6 months, response to mitogen challenge in those receiving the Se was restored to the level of that in healthy young individuals (Peretz et al. 1991).

Additionally, cells of the immune system may have an important functional need for Se. Activated T-cells show upregulated selenophosphate synthetase 2 activity (Guimaraes et al. 1996), directed towards the synthesis of selenocysteine, the essential building block of selenoproteins, demonstrating the importance of selenoproteins to activated T-cell function and the control of the immune response. The mRNA of several T-cell-associated genes (e.g. interleukin 2 receptor $\alpha$ subunit, CD4) have the theoretical capacity to encode functional selenoproteins, suggesting that the roles of $\mathrm{Se}$ in the immune system may be more diverse than previously suspected (Taylor \& Nadimpalli, 1999).

\section{Viral infections}

Se appears to be a key nutrient in counteracting certain viral infections. Elegant work by Beck et al. (1995) has shown that in a Se-deficient host harmless viruses can become virulent. When Se-deficient mice were inoculated with a benign strain of the coxsackie virus, B3/0, mutations occurred in the genome to give a cardiovirulent form of the virus which caused myocarditis with similarities to human pathology. Furthermore, when the virus recovered from these mice was inoculated into Se-adequate mice, it still induced appreciable heart damage, demonstrating the irreversibility of the mutation. In the case of the coxsackie virus six separate point mutations were identified with the development of virulence, causing myocarditis in the host. A similar study on mice unable to make GPxl (GPxlknockout mice) demonstrated that this enzyme is essential for the avoidance of oxidative damage to the genome of the RNA virus, which results in the myocarditic mutations (Beck et al. 1998).

Coxsackie virus has been isolated from the blood and tissues of patients with Keshan disease and is thought likely to be a cofactor in the development of the cardiomyopathy that constitutes this condition (Beck et al. 1995, 1998). It seems probable, therefore, that human Se deficiency similarly affects the viral genome, resulting in the development of the heart pathology.

In more recent work the same group showed that Sedeficient mice infected with a mild strain of influenza virus, influenza $\mathrm{A} / \mathrm{Bangkok} / 1 / 79$, developed much more severe and prolonged lung inflammation than infected Se-adequate mice (Beck et al. 2001). Passage through the Se-deficient animals caused mutations in the virus, which included twenty-nine nucleotide changes in the gene for the M1 matrix protein, an internal viral protein previously thought to be relatively stable. Beck et al. (2001) believe that the changes involve an oxidative-stress mechanism, as in the case of the coxsackie virus described earlier.

It seems clear that Se deficiency can have a profound impact on the genome of RNA viruses, contributing to the 
emergence of new viral strains that may be capable of promoting epidemics (Beck et al. 2001). Other RNA viruses that may be similarly susceptible to mutations resulting in increased virulence are the common cold, HIV, Ebola (Beck et al. 2001), polio and hepatitis. These findings, therefore, have considerable public health implications.

Se seems to be a crucial nutrient for HIV-infected subjects. It is a potent inhibitor of HIV replication in vitro (Sappey et al. 1994). The progress of HIV can be thought of as being synonymous with the progressive loss of CD4+ T-helper cells. More than twenty papers report a progressive decline in plasma Se paralleling the ongoing loss of CD4+ T-cells in HIV-1 (Look et al. 1997). This process occurs even in the early stages of disease where malnutrition or malabsorption cannot be a factor (Look et al. 1997). In fact, plasma $\mathrm{Se}$ is a strong predictor of the outcome in HIV infection. Work carried out by Baum et al. (1997) at the University of Miami, Miami, FL, USA, showed that Sedeficient HIV-infected patients are 19.9 times more likely $(P<0.0001)$ to die from HIV-related causes than those with adequate Se levels. Se deficiency is defined by Baum et al. (1997) as a plasma level $\leq 85 \mu \mathrm{g} / \mathrm{l}$, a level not attained in many northern European countries (see p. 210), e.g. a mean level of $60 \mu \mathrm{g} / 1$ was found in a Scottish study (Shortt et al. 1997). Baum et al. (1997) showed that low plasma Se was significantly associated with mortality (relative risk $10 \cdot 8$, $P<0.002$ ), and conferred a much more significant risk than a low helper $\mathrm{T}$-cell count or deficiency of any other nutrient investigated. In HIV-infected children, low levels of plasma Se were significantly and independently related to mortality (relative risk 5.96, $P=0.02$ ) and faster disease progression (Campa et al. 1999). Clinical trials are now in progress in HIV-infected subjects to investigate the effect of Se supplementation on survival, viral load, CD4 count, immune function and disease progression.

Se also appears to be protective in subjects infected with hepatitis-virus ( $B$ or $C$ ) against the progression of the condition to liver cancer (see pp. 208, 209; Yu et al. 1997; Yu et al. 1999).

It is notable that viruses may be capable of hijacking the Se supply of the host by incorporating Se into viral selenoproteins, thereby reducing the ability of the host to mount an effective immune response. Experimental evidence based on the work of Moss's group (Shisler et al. 1998) suggests that this process is possible in the case of the pox virus, molluscum contagiosum, which makes a homologue of GPx, and both theoretical and experimental evidence from Taylor's group (Zhang et al. 1999) suggests that the ability to make viral selenoproteins (such as GPx) is common to many human viral pathogens, such as HIV-1 and 2, coxsackie virus $\mathrm{B} 3$, hepatitis $\mathrm{B}$ and $\mathrm{C}$, and the measles virus. Good Se status may protect against HIV progression by maintaining host immune competence and appropriate redox control.

\section{Reproduction}

Se has long been recognised in animal husbandry as being essential for successful reproduction (Underwood, 1977; Sanders, 1984). Idiopathic miscarriage has been shown to be associated with Se deficiency in veterinary practice (Stuart
\& Oehme, 1982), while in sheep administration of Se supplements has been shown to prevent early pregnancy loss (Hidiroglou, 1979). Investigating whether this role could also be relevant to man, Barrington et al. $(1996,1997)$ found significantly lower serum $\mathrm{Se}$ in women who suffered either first-trimester $(P=0.0054)$ or recurrent miscarriages $(P=0.014)$. These authors suggest that early pregnancy loss may be linked to reduced antioxidant protection of biological membranes and DNA by relatively low levels of the Se-dependent GPx. A subsequent study found lower Se levels in non-pregnant women suffering recurrent miscarriage than in controls, but the difference did not reach significance (Nicoll et al. 1999). However, the choice of control group can be criticised in this study, as it did not exclude women who had suffered a miscarriage.

$\mathrm{Se}$ is essential for male fertility, being required for testosterone biosynthesis and the formation and normal maturation and development of spermatozoa (Behne et al. 1996; Pfeifer et al. 2001). Se concentration of seminal plasma correlated positively with sperm count $\left(R^{2} 0 \cdot 15\right.$, $P>0.001)$ and total sperm concentration ( $\mathrm{R}^{2} 0.21$, $P>0.001)$ in a group of sub-fertile Norwegian men (Oldereid et al. 1998). Animals fed Se-deficient diets show structural abnormalities in the sperm midpiece which are linked to poor motility and a tendency for the tail to break off (Wu et al. 1973), thus decreasing the chance of fertilisation. An explanation for these findings has recently been afforded by the work of Ursini et al. (1999). They found that a form of GPx (GPx4), believed to shield developing sperm cells from oxidative damage, polymerises in mature sperm into a structural protein in the mitochondrial capsule of the midpiece region. As GPx4 accounts for about $50 \%$ of the capsule material, it seems likely that it is this polymerisation that confers the structural integrity required for sperm stability and motility.

Work carried out at Glasgow Royal Infirmary, Glasgow, UK, supports this interpretation. In studies by Scott \& MacPherson (1998) supplementation of subfertile men with $100 \mu \mathrm{g} \mathrm{Se} / \mathrm{d}$ for 3 months significantly increased sperm motility $(P=0.023)$. Of the men receiving the active supplement $11 \%$ achieved paternity as compared with none in the placebo group. However, administration of double the quantity of Se to subfertile Polish men over a similar period showed no beneficial effect on sperm motility (Iwanier \& Zachara, 1995).

\section{Thyroid function}

Although it is recognised that deiodinase activity is relatively protected in conditions of marginal Se availability (Sunde, 1997), there are some indications that, nonetheless, European levels of $\mathrm{Se}$ intake may compromise thyroid hormone metabolism. For example, values of the plasma triiodothyronine:thyroxine ratio in young Scottish subjects were as low as those normally found in elderly populations (JR Arthur, personal communication). Furthermore, Se supplementation in a small group of elderly subjects decreased plasma thyroxine levels, consistent with increased deiodinase activity and improved conversion to the active hormone, triiodothyronine (Olivieri et al. 1995). Similarly, a supplementation study carried out in Otago, New Zealand 
showed that an additional $10-40 \mu \mathrm{g}$ Se/d significantly decreased $(P<0.05)$ thyroxine concentrations over a period of 20 weeks, implying that the baseline intake of about $30 \mu \mathrm{g} / \mathrm{d}$ was limiting conversion of thyroxine to triiodothyronine (Duffield et al. 1999). When Se and I deficiency are combined, hypothyroidism is exacerbated and may manifest itself as myxoedematous cretinism, such as is seen in the Democratic Republic of Congo (Zaire) where deficiencies of both these minerals exist (Vanderpas et al. 1990).

\section{Mood}

To date, three published studies have linked Se deficiency to adverse mood states. There are a number of indications that $\mathrm{Se}$ is important to the brain: during Se depletion the brain receives a priority supply (Hawkes \& Hornbostel, 1996); the turnover rate of some neurotransmitters is altered in Se deficiency (Castano et al. 1997); supplementation with Se reduced intractable epileptic seizures in children (Weber et al. 1991; Ramaekers et al. 1994) low plasma Se levels in the elderly were found to be significantly associated with senility and accelerated cognitive decline (odds ratio 1.58 (95\% CI 1.08, 2.31); Hawkes \& Hornbostel, 1996; Berr et al. 2000); brain Se concentration in Alzheimer's patients was only $60 \%$ of that in controls (Hawkes \& Hornbostel, 1996). Furthermore, the brain is deficient in catalase (Halliwell \& Gutteridge, 1999), thus peroxidation products such as $\mathrm{H}_{2} \mathrm{O}_{2}$ and primary peroxides must be removed by the antioxidant selenoenzymes.

A number of studies have shown a beneficial effect of Se status on mood, at least when Se status is 'marginal'. In three separate studies low Se status was associated with significantly greater incidence of depression and other negative mood states such as anxiety, confusion and hostility (Benton \& Cook, 1991; Hawkes \& Hornbostel, 1996; Finley \& Penland, 1998). Mood was measured by use of a questionnaire, the 'Profile Of Mood States - Bipolar form'. The higher the score, the better the mood.

In a study carried out in the USA, Se depletion led to depressed mood and more hostile behaviour in those with low initial erythrocyte Se (Hawkes \& Hornbostel, 1996). The lower the initial Se status, the more the mood scores decreased as a result of the low-Se diet. In a second US study, where subjects were fed either a low- or a high-Se diet for 15 weeks, those on the low-Se diet had significantly decreased clearheaded-confused and elated-depressed subscores $(P<0.05$; Finley \& Penland, 1998). The dietary Se intake on this low-Se diet was $32.6 \mu \mathrm{g} / \mathrm{d}$, similar to current UK intakes of $34-39 \mu \mathrm{g} / \mathrm{d}$ (Ministry of Agriculture, Fisheries and Food, 1997, 1999).

In contrast to these findings, high dietary Se or supplementation with Se appears to improve mood. In the US study referred to earlier, those subjects on the high Se $(226.5 \mu \mathrm{g} / \mathrm{d})$ diet significantly improved in the clearheadedconfused, confident-unsure and composed-anxious subscores, and total mood disturbance was significantly less $(P<0.05$; Finley $\&$ Penland, 1998). A similar finding was obtained in a double-blind crossover study carried out in the UK, where a $100 \mu \mathrm{g} / \mathrm{d}$ Se supplement significantly decreased anxiety, depression and tiredness $(P<0.0001$;
Benton \& Cook, 1991), the effect being most marked in those consuming lesser amounts of dietary Se.

The reasons for the effect of Se on mood are unclear, but a number of possibilities come to mind. As thyroid hormones play an important part in the regulation of mood and are involved to some extent in the pathophysiology of mood disorders (Joffe \& Levitt, 1993), the effect could be mediated through the Se-dependent thyroid hormones. Alternatively, Se may help preserve the concentrations of certain neurotransmitters, or influence the level of fatty acids in the brain, either of which could influence mood.

The author is running a 500 subject trial on the effect of Se on mood and thyroid function, results of which should be available in 2002 .

\section{Cancer}

There is growing evidence that higher Se intakes are associated with reduced cancer risk. Two-thirds of animal studies have shown a reduced incidence of tumours from cancer-causing chemicals or viruses with Se supplementation (Combs \& Lï, 2001). Most epidemiological studies carried out since the 1970s have provided evidence of an inverse relationship between Se intake and cancer mortality (Combs \& Gray, 1998).

In prospective studies published in the $1980 \mathrm{~s}$ and early 1990s involving from 8000-11000 subjects, low Se status was associated with a significantly increased risk of cancer incidence and/or mortality. Risk has been from twofold to sixfold higher in the lowest tertile or quintile (according to the study) of serum Se concentration, although in one case the effect was only apparent among males (Kok et al. 1987; Combs \& Gray, 1998).

Studies carried out with the large Finnish Mobile Health Examination Survey cohort have shown a reduced risk of certain cancers, notably cancers of the stomach, pancreas and lung in men (Knekt et al. 1990, 1991). A later nested case-control study within a cohort of 9000 Finnish individuals showed the adjusted relative risk of lung cancer between the highest and lowest tertiles of serum Se to be 0.41 (Knekt et al. 1998). A much smaller study on lung cancer in Chinese tin miners did not show a significant association between $\mathrm{Se}$ and lung cancer incidence in prospectively-collected serum samples. However, median serum Se concentrations in both cases and controls in the latter study were very low (about $46 \mu \mathrm{g} / \mathrm{l}$ ) raising the question of whether likely anti-cancer mechanisms of Se (see p. 210) could operate at these concentrations, especially in a cohort so highly exposed to cigarette smoke, As and Ra (Ratnasinghe et al. 2000). As is known to have the capacity to reduce the anti-cancer effect of some forms of $\mathrm{Se}$ (Combs \& Lï, 2001).

In the case of hepatocellular carcinoma (HCC), a significant inverse association $(\mathrm{P}=0.01)$ was shown between Se levels in stored plasma and later development of the disease in a cohort of 7342 Taiwanese men with chronic hepatitis-virus ( $\mathrm{B}$ or $\mathrm{C}$ ) infection, a noted risk factor for the development of this condition (Yu et al. 1999). However, evidence suggests that Se status may not be an important aetiological factor in breast cancer. In a Finnish study investigating the association between toenail Se and breast 
cancer in 289 cases and 433 community controls, although prediagnostic Se concentrations were lower in the case group, the difference did not reach significance (Mannisto et al. 2000).

A prospective study published by Willett's group (Yoshizawa et al. 1998; also, for commentary, see Taylor \& Albanes, 1998) involved 34000 men from the Harvardbased Health Professionals' Cohort Study. Those participants in the lowest quintile of Se status, as measured by toenail $\mathrm{Se}$, were three times more likely to develop advanced prostate cancer than those in the highest quintile (for trend, $P=0.03$ ). Only cases diagnosed $>2$ years after collection of the samples were counted. A similar casecontrol study on men from the Baltimore Longitudinal Study of Aging registry showed that after correcting for number of years before diagnosis, BMI and smoking and alcohol-use history, higher Se was associated with a lower risk of prostate cancer (Brooks et al. 2001). Compared with the lowest quartile of Se (range 82-107 $\mu \mathrm{g} / 1$ ), the odds ratios of the second (108-118), third (119-132) and fourth (133-182) quartiles were 0.15 (95\% CI $0.05,0.50), 0.21$ (95\% CI $0.07,0.68)$ and $0.24(95 \%$ CI $0.08,0.77)$, respectively $(\mathrm{P}=0.01)$. Thus, in this study low plasma $\mathrm{Se}$ was associated with a four-to fivefold increased risk of prostate cancer.

There have been few intervention trials using Se as a single agent. A number of these trials have been carried out in China, where $\mathrm{HCC}$ is the third highest cause of cancer mortality. In the Qidong county, about $60 \mathrm{~km}$ north of Shanghai, the incidence of $\mathrm{HCC}$ is particularly high. In this region about $15 \%$ of adults carry the hepatitis $B$ surface antigen and these individuals are 200 times more likely to develop HCC. In a study where 226 carriers of hepatitis B antigen were randomised to either $200 \mu \mathrm{g}$ Se-enriched yeast or placebo, no case of HCC occurred in the supplemented group after 4 years, while seven subjects in the placebo group had developed HCC (Yu et al. 1997). In another study, table salt fortified with Se reduced $\mathrm{HCC}$ incidence in a Chinese township by $35 \%$ over a period of 6 years compared with control townships (Yu et al. 1997).

The Nutritional Prevention of Cancer (NPC) trial carried out by Clark et al. (1996) in the USA was the first double-blind placebo-controlled intervention trial in a Western population designed to test the hypothesis that Se supplementation could reduce the risk of cancer. In 1312 subjects with a history of non-melanoma skin cancer who were randomised to placebo or $200 \mu \mathrm{g}$ Se (as Se-enriched yeast)/d, there was no effect on the primary end point of non-melanoma skin cancer. However, those subjects receiving Se showed secondary end-point effects of $50 \%$ lower total cancer mortality $(P=0.002)$ and $37 \%$ lower total cancer incidence $(P=0.001)$, with $63 \%$ fewer cases of cancer of the prostate, $58 \%$ fewer cases of cancer of the colon and $46 \%$ fewer cases of cancer of the lung.

Analysis of treatment effect in different subgroups in the NPC trial has given some interesting results, although these must be treated with caution, as the numbers of events are low and the role of chance cannot be excluded. When subjects were divided into tertiles on the basis of initial plasma Se status, the strongest treatment effect was observed in subjects in the lowest tertile of plasma Se, i.e. those whose plasma Se concentration was $<106 \mu \mathrm{g} / 1$ at entry to the trial (see Table 2; Rayman \& Clark, 2000). Se supplementation reduced the risk of cancer in this tertile by $48 \%$.

Plasma or serum Se concentrations (more or less equivalent) measured in the $1990 \mathrm{~s}$ in a selected number of European locations are shown for comparison in Fig. 1. The upper level of the bottom tertile in the NPC trial is indicated on Fig. 1, and it is apparent that these locations fall well within that bottom tertile. Consequently, it might be predicted that a repeat of the NPC trial in these European locations would show a very marked treatment effect. (This is effectively what is planned in the Prevention of Cancer by Intervention with Se (PRECISE) trial, where Denmark, Sweden and the UK (where the author is cohort leader) will participate in an extended repeat of the NPC trial, recruiting equal numbers of men and women. PRECISE pilot studies are already well advanced.) NPC trial results also imply that an increase in Se intake to an 'appropriate' level has the potential to reduce cancer risk in many European countries.

Contrary to the effect seen in the bottom tertile, subjects in the top tertile at entry to the trial, whose plasma concentration was $\geq 121 \mu \mathrm{g} /$, appeared to derive no additional reduction in risk from the supplementary Se. Combs (2001) suggests that the level of dietary intake (about $1.5 \mu \mathrm{g} / \mathrm{kg}$ body weight per d) required to achieve this plasma concentration (about $120 \mu \mathrm{g} / \mathrm{l}$ ) might therefore be a target to aim for in order to minimise cancer risk.

\section{Evidence that supra-nutritional levels of selenium may be beneficial}

From the information cited earlier, it is clear that there are some cases where levels of intake above those believed to be required for repletion of the selenoenzymes (Alfthan et al. 1991; Thomson et al. 1993; Duffield et al. 1999), may give

Table 2. Total cancer incidence $1983-96$ by plasma selenium level at baseline for subjects participating in the Nutritional Prevention of Cancer trial (from Rayman \& Clark, 2000)

\begin{tabular}{|c|c|c|c|c|c|}
\hline Baseline plasma Se $(\mu g / l)^{*}$ & $\begin{array}{c}\text { Se group } \\
\text { no. of cases } t\end{array}$ & $\begin{array}{l}\text { Placebo group } \\
\text { no. of cases }\end{array}$ & $\mathrm{RR}$ & $95 \% \mathrm{Cl}$ & $\begin{array}{c}\text { Statistical significance of difference } \\
\text { between treatment groups: } P=\end{array}$ \\
\hline$<106$ & 28 & 56 & 0.52 & $0.33,0.82$ & 0.005 \\
\hline $106-121$ & 34 & 49 & 0.64 & $0.40,0.97$ & 0.40 \\
\hline$>121$ & 45 & 41 & 1.00 & $0.65,1.54$ & 0.99 \\
\hline
\end{tabular}

$\mathrm{RR}$, relative risk.

* Se status at entry to trial.

† subjects received Se-enriched yeast $(200 \mu \mathrm{g} \mathrm{Se} / \mathrm{d})$. 


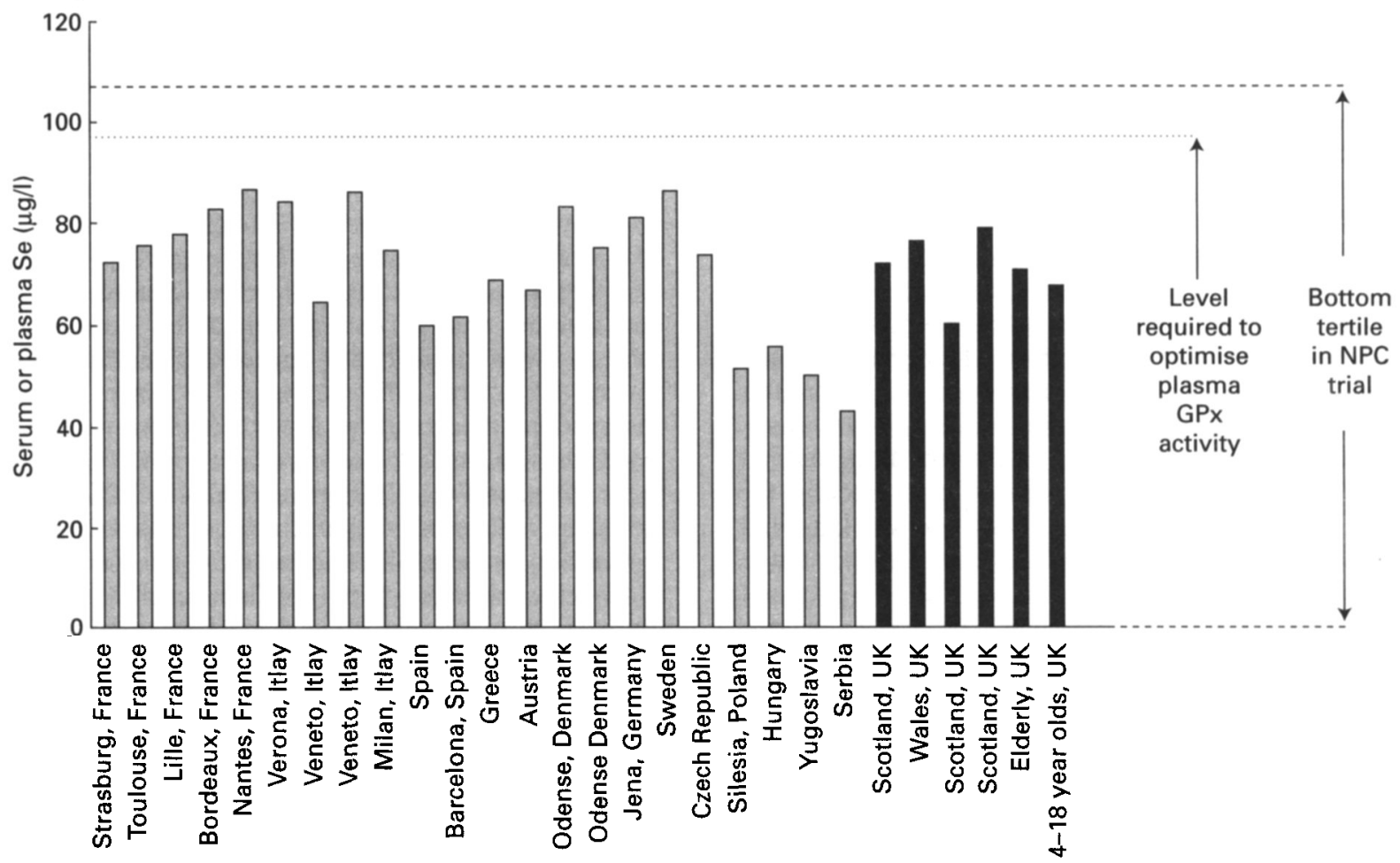

Fig. 1. Recent mean levels of serum or plasma selenium in Europe compared with ( ----), bottom tertile in Nutritional Prevention of Cancer (NPC) trial of Clark et al. (1996); (…), level required for optimal plasma glutathione peroxidase (GPx) activity (Alfthan et al. 1991; Thomson et al. 1993; Duffield et al. 1999).

additional health benefits. This situation appears to be valid for the immune system, where intakes of $200 \mu \mathrm{g} / \mathrm{d}$ in a Se-replete group of volunteers greatly magnified the production of cytotoxic $\mathrm{T}$-cells and natural killer cells, thus enhancing cancer-protective capacity (KiremidjianSchumacher et al. 1994). Similarly, supplementation in the NPC trial was largely of subjects whose baseline Se intakes of about $90 \mu \mathrm{g} / \mathrm{d}$ (Clark et al. 1996) were such that their selenoenzyme activities, as represented by plasma GPx, would already have been maximal. In those subjects, an additional $200 \mu \mathrm{g} \mathrm{Se} / \mathrm{d}$ was found to be effective in reducing cancer incidence and mortality. However, distinct selenoproteins may exhibit different expression patterns at high concentrations of $\mathrm{Se}$, or when individuals are under environmental or genetic stress, so we cannot assume that selenoproteins, some of which may be unknown as yet, are not involved in cancer prevention (Gladyshev, 2001b). (Indeed, there is a suggestion that GPx2 may be important in protection from colon cancer and that the $15 \mathrm{kDa}$ selenoprotein may protect against malignancy, particularly of the prostate (Wingler et al. 1999, 2000; Gladyshev, 2001b).)

It is clear from these studies that intakes of Se above the normal 'nutritional' range may confer further benefit. In the case of cancer, evidence suggests that these supranutritional intakes may further enhance the immune response and provide sufficient concentration of Se metabolites, such as methyl selenol, that can induce apoptosis of cancer cells, block cell division and inhibit tumour neo-angiogenesis (Kaeck et al. 1997; Sinha \& Medina, 1997; Ip, 1998; Jiang et al. 2000; Ghose et al. 2001; Fleming et al. 2001; for a review of anti-cancer mechanisms of Se, see Combs \& Lu, 2001).

\section{Selenium intake and status may be inadequate in many countries}

Se enters the food chain through plants, but its incorporation is dependent not only on soil content and geochemistry but also on soil $\mathrm{pH}$, rainfall, land contour and microbial activity (Diplock, 1993; Reilly, 1996c); some bacteria can convert insoluble forms of Se to soluble forms that can be taken up by the plant (Diplock, 1993). Availability of Se to populations in different parts of the world is thus highly variable, and is notably low in parts of China, New Zealand, parts of Eastern Europe, Russia and Africa (Combs, 2001). Tables of Se intakes in several countries from the 1980s onwards and of European intakes from the 1990s have been published by Combs (2001) and Rayman (2000) respectively.

The situation in much of Europe is giving some cause for concern, largely because of recent falls in Se intake (e.g. Denmark where intake fell from 51 to $42 \mu \mathrm{g} / \mathrm{d}$ over the 5-year period 1990-1995; Bro et al. 1990; Danish Governmental Food Agency, 1995). Mean UK daily intakes since 1974 are shown in Fig. 2. It can be seen that there has been a reduction in intake from $60-63 \mu \mathrm{g} / \mathrm{d}$ to the current level of $34-39 \mu \mathrm{g} / \mathrm{d}$ (Barclay et al. 1995; Ministry of Agriculture Fisheries and Food, 1997, 1999). The UK 


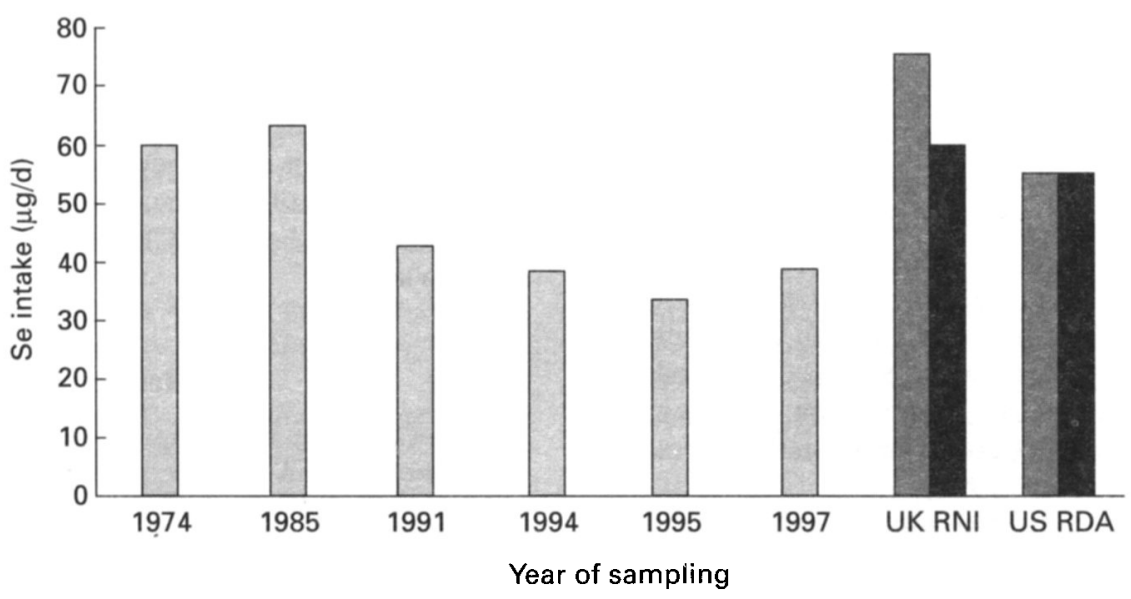

Fig. 2. Current and recent selenium intake in the UK (Ministry of Agriculture, Fisheries and Food, 1997, 1999). (西), Male; (四), female. RNI, reference nutrient intake; RDA, recommended daily allowance.

reference nutrient intakes for males and females (75 and $60 \mu \mathrm{g} / \mathrm{d}$ respectively; Department of Health, 1991) and the US recommended daily allowance $(55 \mu \mathrm{g} / \mathrm{d}$; Food and Nutrition Board, Institute of Medicine, 2000) are also shown. Clearly, our current intake does not meet either the reference nutrient intake or the recommended daily allowance. Many individuals will be aware that the fall in intake in recent years is believed to result from the reduced importation of North American (largely Canadian) wheat for bread-making (MacPherson et al. 1997). This wheat was high in Se but we imported it because it was high in protein (so-called hard wheat) and enabled the bread dough to rise satisfactorily. We now use lower-protein EU varieties and increase the protein content by adding gluten, a protein byproduct of the starch industry, to help the dough to rise.

The reduction in Se intake in the UK has been paralleled by a reduction in Se status, as measured by serum, plasma or whole-blood Se (Rayman, 1997). Recent UK measurements, each on approximately 1000 subjects, from the National Diet and Nutrition Surveys of the elderly and of adults and children, found mean plasma Se to be $71 \mu \mathrm{g} / 1$ (in 1994-5) and $68 \mu \mathrm{g} / \mathrm{l}$ (in 1997) respectively (Gregory et al. 2000; Bates et al. 2002). Thus, current plasma or serum Se concentrations in the UK and many other European locations, as shown in Fig. 1, do not allow maximal expression of plasma GPx (Alfthan et al. 1991; Thomson et al. 1993; Duffield et al. 1999), the criterion for Se sufficiency adopted by most authorities when setting their dietary reference values.

Furthermore, in the light of the apparently beneficial effects of supra-nutritional intakes of Se described earlier, it may no longer be appropriate to rely on such a marker as an indicator of adequacy of Se intake. Not only, then, are many European locations failing to meet the standards of adequacy set according to antioxidant GPx activity, but the additional potential benefit of reducing cancer risk by intakes capable of raising our plasma Se to $\geq 120 \mu \mathrm{g} / \mathrm{l}$ (Combs, 2001) is presently quite unattainable (except by individual supplementation).

\section{Increasing selenium intake is feasible}

There are not many naturally rich sources of Se in European foods. Brazil nuts, kidneys and crab are the richest sources (Barclay et al. 1995), but are hardly likely to be eaten in any great quantity. Thus, increasing Se intake from normal food sources is difficult to achieve. Other solutions must be considered, one of which has already proved successful.

In order to safeguard the health of its population and to overcome Se deficiency diseases in domestic animals, Finland, since 1984, has been adding Se to its food supply by treating crops with fertiliser containing $\mathrm{Na}_{2} \mathrm{SeO}_{4}$. This action has altered Se intake from $38 \mu \mathrm{g} / \mathrm{d}$ per $10 \mathrm{MJ}$ in 1984 , before Se-enriched fertiliser treatment, to a maximum level of $124 \mu \mathrm{g} / \mathrm{d}$ per $10 \mathrm{MJ}$ (Eurola \& Hietaniemi, 2000). Plasma Se has varied from 87 to $121 \mu \mathrm{g} / \mathrm{l}$, depending on the level of fertiliser application, which has been changed twice since 1984 , being last altered in 1998 from 6 to $10 \mathrm{mg} \mathrm{Se} / \mathrm{kg}$ fertiliser for all crops (Eurola \& Hietaniemi, 2000). Se intake was measured as $65 \mu \mathrm{g} / \mathrm{d}$ per $10 \mathrm{MJ}$ in 1999 , while plasma Se concentration was determined as $97 \mu \mathrm{g} / \mathrm{l}$ in 2000 (Alfthan, 2001), although neither of these levels may yet have plateaued.

Careful monitoring of levels in foods, grains, soils and water, and of human Se status has been carried out during these years. There have been no adverse environmental effects; residual Se concentrations in areas under cultivation, surface waters and lake sediments have not changed (Eurola \& Hietaniemi, 2000). The Finnish experience shows that, at least in the geochemical environment of Finland, it is possible to increase Se intake to attain the plasma concentration where plasma GPx is optimally active, or even to reach $121 \mu \mathrm{g} / \mathrm{l}$, the plasma concentration above which supplementary Se gave no further reduction in cancer risk in the NPC trial (Rayman \& Clark, 2000; Combs, 2001).

Fortification of foods with $\mathrm{Se}$ is another option. This process has already been satisfactorily achieved for the minerals $\mathrm{Ca}$ and $\mathrm{Fe}$ with which flour is fortified by statute. Clearly, great care would have to be taken to ensure that an appropriate form of Se was selected, and that a concen- 
tration with a wide margin of safety was used, owing to the toxicity of Se. However, levels of intake required for toxicity are higher than those generally assumed; thus, for a $70 \mathrm{~kg}$ man, a 'no observed adverse effect' level of intake is about $1000 \mu \mathrm{g} / \mathrm{d}$, with low adverse effects (hair loss and nail changes) appearing at about $2000 \mu \mathrm{g} / \mathrm{d}$ and toxicity (selenosis) at $6300 \mu \mathrm{g} / \mathrm{d}(\mu \mathrm{g} / \mathrm{kg}$ body weight per $\mathrm{d}$; no observed adverse effect level 15 , low adverse effect level 28, selenosis level 90; Whanger et al. 1996). Nonetheless, supplementation of fertilisers with $\mathrm{Se}$, as practised in Finland, has the advantage that plants form a biological barrier that protects the target population from the effects of accidental overdose (Aro et al. 1998).

In the absence of government action in most countries, it has been a tempting proposition for manufacturers to develop functional foods containing Se. High-Se vegetables, beer, tea, mushrooms and mussels are described by Combs (2001). Korea has a chain of restaurants selling pork fed with organic Se, 'Selenpork' (Cole, 2000). A Se-enriched egg was developed at the Scottish Agricultural College, Edinburgh, UK (Surai et al. 2000). Interestingly, both the pork and the eggs have improved keeping qualities. Marks and Spencer (London, UK) has developed a range of foods, the 'and More' range, that contain $50 \mu \mathrm{g}$ Se per serving. A feasible way to increase Se intake would be to fortify bread with Se, which has the virtue of being a 'staple'. The UK supermarket chain ASDA (Asda Stores Ltd, Leeds, UK) already sells a type of bread in its bakeries made from Canadian flour, which is a good source of Se. At least one bakery is selling Brazil-nut bread (The Village Bakery, Melmerby, Cumbria, UK).

Clearly there are many possibilities if the need is accepted, but a public health solution must be found which extends to the less-well-off, whose health needs are greatest.

\section{Conclusion}

Avoidance of deficiency diseases is no longer seen as an adequate goal for nutrition; we are now seeking to optimise our dietary intake so that we may postpone the onset of degenerative diseases and avoid long spells of incapacity in our older years. Brown \& Arthur (2001) have suggested that chronic marginal intakes of Se may culminate in chronic diseases such as cancer, cardiovascular disease and increased susceptibility to viral infection. The health effects of Se described earlier reinforce this statement and provide a cogent argument for increasing the intake of Se. This level should be at least to that accepted as optimising selenoenzyme activity in countries such as the UK where such optimal activities are not now achieved. While it is clear that an intake to this level would be beneficial in some health conditions, others such as the immune function or cancer may require an additional 'supra-nutritional' intake, which may be about $200 \mu \mathrm{g} / \mathrm{d}$. This crucial point can only be clarified when current or planned intervention trials have yielded results. PRECISE, Se and Vitamin E (prostate) Cancer Prevention Trial (SELECT) and the HIV and AIDS trials have the potential to reinforce or refute the argument for increasing Se intake to supra-nutritional levels.

\section{Acknowledgements}

The original source of some of the material in this paper is the author's own article (Rayman, 2000); Lancet has kindly given permission to reproduce this material.

The support of the Cancer Research Campaign for the UK pilot of the PRECISE clinical trial is gratefully acknowledged.

\section{References}

Alfthan G, Aro A, Arvilommi H \& Huttunen JK (1991) Selenium metabolism and platelet glutathione peroxidase activity in healthy Finnish men: effect of selenium yeast, selenite, and selenate. American Journal of Clinical Nutrition 53, 120-125.

Alfthan GV (2001) Dietary intake and blood levels of selenium in Finland in the 1970s to 1990s: the effect of fortification of fertilizers. Third International Conference on Natural Antioxidants and Anticarcinogens in Food, Health and Disease, June 6-9, 2001, Helsinki, Finland, Abstracts, p. 66 [S Voutilainen and $\mathrm{J}$ Salonen, editors]. Kuopio, Finland: Kuopio University Publications.

Allan CB, Lacourciere GM \& Stadtman TC (1999) Responsiveness of selenoproteins to dietary selenium. Annual Review of Nutrition 19, 1-16.

Angstwurm MWA, Schottdorf J, Schopohl J \& Gärtner R (1999) Selenium replacement in patients with severe systemic inflammatory response syndrome improves clinical outcome. Critical Care Medicine 27, 1807-1813.

Aro A, Alfthan G, Ekholm P \& Varo P (1998) Effects of selenium supplementation of fertilizers on human nutrition and selenium status. In Environmental Chemistry of Selenium, pp. 81-97 [WT Frankenberger Jr and RA Engberg, editors]. New York: Marcel Dekker Inc.

Arteel GA, Briviba K \& Sies H (1999) Protection against peroxynitrite. FEBS Letters 445, 226-230.

Barclay MNI, MacPherson A \& Dixon J (1995) Selenium content of a range of UK foods. Journal of Food Composition and Analysis 8, 307-318.

Barrington JW, Lindsay P, James D, Smith S \& Roberts A (1996) Selenium deficiency and miscarriage: a possible link? British Journal of Obstetrics and Gynaecology 103, 130-132.

Barrington JW, Taylor M, Smith S \& Bowen-Simpkins P (1997) Selenium and recurrent miscarriage. Journal of Obstetrics and Gynaecology 17, 199-200.

Bates CJ, Thane CW, Prentice A \& Delves HT (2002) Selenium status and its correlates in a British national diet and nutrition survey: people aged 65 years and over. Journal of Trace Elements in Medicine and Biology 16, 1-8.

Baum MK, Shor-Posner G, Lai S, Zhang G, Lai H, Fletcher MA, Sauberlich H \& Page JB (1997) High risk of HIV-related mortality is associated with selenium deficiency. Journal of Acquired Immune Deficiency Syndrome 15, 370-374.

Beck MA, Esworthy RS, Ho Y-S \& Chu F-F (1998) Glutathione peroxidase protects mice from viral-induced myocarditis. FASEB Journal 12, 1143-1149.

Beck MA, Nelson HK, Shi Q, Van Dael P, Schiffrin EJ, Blum S, Barclay D \& Levander OA (2001) Selenium deficiency increases the pathology of an influenza virus infection. FASEB Journal 15, 1481-1483.

Beck MA, Shi Q, Morris VC \& Levander OA (1995) Rapid genomic evolution of a non-virulent Coxsackievirus B3 in selenium-deficient mice results in selection of identical virulent isolates. Nature Medicine 1, 433-436.

Behne D, Kyriakopoulos A, Kalcklosh M, Weiss-Nowak C, Pfeifer H, Gessner H \& Hamel C (1997) Two new selenoproteins found 
in the prostatic glandular epithelium and the spermatid nuclei. Biomedical and Environmental Science 10, 340-345.

Behne D, Pfeifer H, Rothlein D \& Kyriakopoulos (2000) Cellular and subcellular distribution of selenium and selenoproteins. In Trace Elements in Man and Animals-10: Proceedings of the Tenth International Symposium on Trace elements in Man and Animals, pp. 29-33 [AM Roussel, A Favier and RA Anderson, editors]. New York: Plenum Press.

Behne D, Weiler H \& Kyriakopoulos A (1996) Effects of selenium deficiency on testicular morphology and function in rats. Journal of Reproductive Fertility 106, 291-297.

Benton D \& Cook R (1991) Biological selenium supplementation improves mood in a double-blind crossover trial. Psychopharmacology 29, 1092-1098.

Berr C, Balansard B, Arnaud J, Roussel AM \& Alperovitch A (2000) Cognitive decline is associated with systemic oxidative stress - the EVA study. Journal of the American Geriatric Society 48, 1285-1291.

Bro S, Sandstrom B \& Heydorn K (1990) Intake of essential and toxic trace elements in a random sample of Danish men as determined by the duplicate portion sampling technique. Journal of Trace Elements and Electrolytes in Health and Disease 4, 147-155.

Brooks JD, Metter EJ, Chan DW, Sokoll LJ, Landis P, Nelson WG, Muller D, Andres R \& Carter HB (2001) Plasma selenium level before diagnosis and the risk of prostate cancer development. Journal of Urology 166 (6), 2034-38.

Brown KM \& Arthur JR (2001) Selenium, selenoproteins and human health: a review. Public Health Nutrition 4, 593-599.

Campa A, Shor-Posner G, Indacochea F, Zhang G, Lai H, Asthana D, Scott GB \& Baum MK (1999) Mortality risk in seleniumdeficient HIV-positive children. Journal of Acquired Immune Deficiency Syndrome 20, 508-513.

Castano A, Ayala A, Rodriguez-Gomez JA, Herrera AJ, Cano J \& Machado A (1997) Low selenium diet increases the dopamine turnover in prefrontal cortex of the rat. Neurochemistry International 30, 549-555.

Clark LC, Combs GF Jr, Turnbull BW, Slate EH, Chalker DK, Chow J, Davis LS, Glover RA, Graham GF, Gross EG, Kongrad A, Lesher JL Jr, Kim Park H, Sanders BB Jr, Smith CL \& Taylor R for the Nutritional Prevention of Cancer Study Group (1996) Effects of selenium supplementation for cancer prevention in patients with carcinoma of the skin: A randomized controlled trial. Journal of the American Medical Association 276, 1957-1963 (erratum in Journal of the American Medical Association (1997) 277, 1520).

Cole DJA (2000) Selenium, the pig and the human diet. In Concepts in Pig Science 2000, pp. 149-158 [TP Lyons and DJA Cole, editors]. Nottingham: Nottingham University Press.

Combs GF Jr (2001) Selenium in global food systems. British Journal of Nutrition 85, 517-547.

Combs GF Jr \& Gray WP (1998) Chemopreventive agents: selenium. Pharmacology and Therapeutics 79, 179-192.

Combs GF Jr \& Lü J (2001) Selenium as a cancer preventive agent. In Selenium: Its Molecular Biology and Role in Human Health, pp. 205-218 [DL Hatfield, editor]. Dordrecht, The Netherlands: Kluwer Academic Publishers.

Coppinger RJ \& Diamond AM (2001) Selenium deficiency and human disease. In Selenium: Its Molecular Biology and Role in Human Health, pp. 219-233 [DL Hatfield, editor]. Dordrecht, The Netherlands: Kluwer Academic Publishers.

Danish Governmental Food Agency (1995) Food Habits of Danes 1995 Main Results. Soeborg, Denmark: Levnedsmiddelstyrelsen.

Department of Health (1991) Dietary Reference Values for Food Energy and Nutrients for the UK Report on Health and Social Subjects no. 41 London: H. M. Stationery Office.
Diplock AT (1993) Indexes of selenium status in human populations. American Journal of Clinical Nutrition 57, Suppl., 256S-258S.

Diplock AT (1994) Antioxidants and disease prevention. Molecular Aspects of Medicine 15, 293-376.

Duffield AJ, Thomson CD, Hill KE \& Williams S (1999) An estimation of selenium requirements for New Zealanders. American Journal of Clinical Nutrition 70, 896-903.

Eurola M \& Hietaniemi V (editors) (2000) Report of the Selenium Monitoring Programme 1997-1999. Publications of Agricultural Research Centre of Finland, Serie B 24. Jokioinen, Finland: Agricultural Research Centre of Finland.

Finley JW \& Penland JG (1998) Adequacy or deprivation of dietary selenium in healthy men: clinical and psychological findings. Journal of Trace Elements in Experimental Medicine 11, 11-27.

Fleming J, Ghose A \& Harrison PR (2001) Molecular mechanisms of cancer prevention by selenium compounds. Nutrition and Cancer 40, 42-49.

Food and Nutrition Board, Institute of Medicine, the National Academies with Health Canada (2000) Dietary Reference Intakes for Vitamin C, Vitamin E, Selenium, and Carotenoids. Washington, DC: National Academy Press.

Ghose A, Fleming J \& Harrison PR (2001) Selenium and signal transduction: roads to cell death and anti-tumour activity. Biofactors 14, 127-133.

Gladyshev VN (2001a) Identity, evolution and function of selenoproteins and selenoprotein genes. In Selenium: Its Molecular Biology and Role in Human Health, pp. 99-104 [DL Hatfield, editor]. Dordrecht, The Netherlands: Kluwer Academic Publishers.

Gladyshev VN (2001b) The $15 \mathrm{kDa}$ selenoprotein (Sep15): functional studies and a role in cancer etiology. In Selenium: Its Molecular Biology and Role in Human Health, pp. 147-156 IDL Hatfield, editor]. Dordrecht, The Netherlands: Kluwer Academic Publishers.

Gregory J, Lowe S, Bates CJ, Prentice A, Jackson LV, Smithers G, Wenlock R \& Farron M (2000) National Diet and Nutrition Survey: Young People Aged 4 to 18 years. vol. 1. Report of the Diet and Nutrition Survey. London: The Stationery Office.

Guimaraes MJ, Peterson D, Vicari V, Cocks BG, Copeland NG, Gilbert DJ, Jenkins NA, Ferrick DA, Kastelain RA, Bazan JF \& Zlotnik A (1996) Identification of a novel selD homolog from Eukaryotes, Bacteria, and Archea: Is there an autoregulatory mechanism in selenocysteine metabolism? Proceedings of the National Academy of Sciences USA 93, 15068-15091.

Halliwell B \& Gutteridge JMC (1999) Free Radicals in Biology and Medicine, 3rd ed., pp. 135, 729. Oxford: Oxford University Press.

Hasselmark L, Malmgren R, Zetterstrom O \& Unge G (1993) Selenium supplementation in intrinsic asthma. Allergy 48, 30-36.

Hawkes WC \& Hornbostel L (1996) Effects of dietary selenium on mood in healthy men living in a metabolic research unit. Biological Psychiatry 39, 121-128.

Hidiroglou M (1979) Trace element deficiencies and fertility in ruminants: a review. Journal of Dairy Science 62, 1195-1206.

Hill KE \& Burk RF (2001) Selenoprotein P. In Selenium: Its Molecular Biology and Role in Human Health, pp. 123-136 [DL Hatfield, editor]. Dordrecht, The Netherlands: Kluwer Academic Publishers

Ip C (1998) Lessons from basic research in selenium and cancer prevention. Journal of Nutrition 128, 1845-1854.

Iwanier K \& Zachara B (1995) Selenium supplementation enhances the element concentration in blood and seminal fluid but does not change the spermatozoal quality characteristics in subfertile men. Journal of Andrology 16, 441-447.

Jiang C, Jiang W, Ip C, Ganther H \& Lu J (1999) Selenium-induced inhibition of angiogenesis in mammary cancer at chemo- 
preventive levels of intake. Molecular Carcinogenesis 26 , 213-225.

Joffe RT \& Levitt AJ (1993) The thyroid and depression. In The Thyroid Axis and Psychiatric Illness, pp. 195-253 [RT Joffe and AJ Levitt, editors]. Washington, DC: American Psychiatric Press Inc.

Kaeck M, Lu J, Strange R, Ip C, Ganther HE \& Thompson HJ (1997) Differential induction of growth arrest inducible genes by selenium compounds. Biochemical Pharmacology 53, 921-926.

Kardinaal AFM, Kok FJ, Kohlmeier L, Martin-Moreno M, Ringstad J, Gomez-Aracena J, Mazaev VP, Thamm M, Martin BC, van't Veer P \& Huttunen JK (1997) Association between toenail Se and risk of myocardial infarction in European men. The Euramic Study. American Journal of Epidemiology 145, 373-379.

Kiremidjian-Schumacher L, Roy M, Glickman R, Schneider K, Rothstein S, Cooper J, Hochster H, Kim M \& Newman R (2000) Selenium and immunocompetence in patients with head and neck cancer. Biological Trace Element Research 73, 97-111.

Kiremidjian-Schumacher L, Roy M, Wishe HI, Cohen MW \& Stotzky G (1994) Supplementation with selenium and human immune cell functions. Biological Trace Element Research 41, 115-127.

Knaus WA, Draper EA, Wagner DP \& Zimmermann JE (1985) APACHE-II: A severity of disease classification system. Critical Care Medicine 13, 818-829.

Knaus WA, Wagner DP, Draper EA, Zimmerman JE, Bergner M, Bastos PG et al. (1991) The APACHE III prognostic system. Risk prediction of hospital mortality for critically ill hospitalized adults. Chest 100, 1619-1936.

Knekt P (2002) Selenium status and prevention of chronic diseases. In Handbook of Antioxidants, 2nd ed., pp. 665-687 [E Cadenas and L Packer, editors]. New York: Marcel Dekker Inc.

Knekt P, Aromaa A, Maatela J, Alfthan G, Aaran RK, Hakama M, Hakulinen T, Peto R \& Tepo L (1990) Serum selenium and subsequent risk of cancer among Finnish men and women. Journal of the National Cancer Institute 82, 864-868.

Knekt P, Aromaa A, Maatela J, Alfthan G, Aaran RK, Nikkari T, Hakama M, Hakulinen T \& Tepo L (1991) Serum micronutrients and risk of cancers of low incidence in Finland. American Journal of Epidemiology 134, 356-361.

Knekt P, Heliövaara M, Aho K, Alfthan G, Marniemi J \& Aromaa A (2000) Serum selenium, serum alpha-tocopherol and the risk of rheumatoid arthritis. Epidemiology 11, 402-405.

Knekt P, Marniemi J, Teppo L, Heliövara M \& Aromaa A (1998) Is low selenium status a risk factor for lung cancer? American Journal of Epidemiology 148, 975-982.

Kok FJ, de Bruijn AM, Hofman A, Vermeeren R \& Valkenburg HA (1987) Is serum a risk factor for cancer in men only? American Journal of Epidemiology 125, 12-16.

Kuklinsky B \& Schweder R (1996) Acute pancreatitis, a free radical disease; reducing the lethality with sodium selenite and other antioxidants. Journal of Nutritional and Environmental Medicine 6, 393-394.

Kukreja R \& Khan A (1998) Effect of selenium deficiency and its supplementation on DTH response, antibody forming cells and antibody titre. Indian Journal of Experimental Biology 36, 203-205.

Look MP, Rockstroh JK, Rao GS, Kreuzer KA, Spengler U \& Sauerbruch T (1997) Serum selenium versus lymphocyte subsets and markers of disease progression and inflammatory response in Human Immunodeficiency Virus-infection. Biological Trace Element Research 56, 31-41.

McCloy R (1998) Chronic pancreatitis at Manchester, UK: focus on antioxidant therapy. Digestion 59, Suppl. 4, 36-48.

MacPherson A, Barclay MNI, Scott R \& Yates RWS (1997) Loss of Canadian wheat lowers selenium intake and status of the
Scottish population. In Trace Elements in Man and Animals-9: Proceedings of the Ninth International Symposium on Trace Elements in Man and Animals pp. 203-205 [PWF Fischer, MR L'Abbé, KA Cockell and RS Gibson, editors]. Ottawa, Ont.: NRC Research Press.

Mannisto S, Alfthan G, Virtanen, Uusitupa $M$ \& Pietinen $P$ (2000) Toenail selenium and breast cancer - a case-control study in Finland. European Journal of Clinical Nutrition 54, 98-103.

Ministry of Agriculture, Fisheries and Food (1997) Dietary intake of Selenium Food Surveillance Information Sheet no. 126. London: Joint Food Safety and Standards Group.

Ministry of Agriculture, Fisheries and Food (1999) Total Diet Study - Aluminium, Arsenic, Cadmium, Chromium, Copper, Lead, Mercury, Nickel, Selenium, Tin and Zinc. Food Surveillance Information Sheet no. 191. London: Joint Food Safety and Standards Group.

Moreno-Reynes R, Suetens C, Mathieu F, Begaux F, Zhu D, Rivera MT, Boelaert M, Nève J, Perlmutter N \& Vanderpas J (1998) Kashin-Beck osteoarthropathy in rural Tibet in relation to selenium and iodine status. New England Journal of Medicine 339, 1112-1120.

Nève J (1996) Selenium as a risk factor for cardiovascular diseases. Journal of Cardiovascular Risk 3, 42-47.

Nicol C, Herdman J, Sattar N, O'Dywer, O'Reilly D, Littlejohn D \& Fell G (1998) Changes in concentrations of plasma selenium and selenoproteins after minor elective surgery: further evidence for a negative acute phase response. Clinical Chemistry 44 , 1764-1766.

Nicoll AE, Norman J, MacPherson A \& Acharya U (1999) Association of reduced selenium status in the aetiology of recurrent miscarriage. British Journal of Obstetrics and Gynaecology 106, 1188-1191.

Oldereid NB, Thomassen Y \& Purvis K (1998) Selenium in human male reproductive organs. Human Reproduction 13, 2172-2176.

Olivieri O, Girelli D, Azzini M, Stanzial AM, Russo C, Ferroni M \& Corrocher R (1995) Low selenium status in the elderly influences thyroid hormones. Clinical Science 89, 637-642.

Peretz A, Neve J, Desmedt J, Duchateau J, Dramaix M \& Famaey JP (1991) Lymphocyte response is enhanced by supplementation of elderly subjects with selenium-enriched yeast. American Journal of Clinical Nutrition 53, 1323-1328.

Peretz A, Néve J, Duchateau JP \& Famaey JP (1992) Adjuvant treatment of recent onset rheumatoid arthritis by selenium supplementation: preliminary observations. British Journal of Rheumatology 31, 281-286.

Peretz A, Siderova V \& Néve J (2001) Selenium supplementation in rheumatoid arthritis investigated in a double blind, placebocontrolled trial. Scandinavian Journal of Rheumatology 30, 208212.

Pfeifer H, Conrad M, Roethlein D, Kyriakopoulos A, Brielmeier M, Bornkamm GW \& Behne D (2001) Identification of a specific sperm nuclei selenoenzyme necessary for protamine thiol cross-linking during sperm maturation. FASEB Journal 15, 1236-1238.

Ramaekers VTh, Calomme M, Vanden Berghe D \& Makropoulos W (1994) Selenium deficiency triggering intractible seizures. Neuropediatrics 25, 217-223.

Ratnasinghe D, Tangrea JA, Forman MR, Hartman T, Gunter EW, Qiao Y-L, Yao S-X, Barett MJ, Giffen CA, Erozan Y, Tockman MS \& Taylor PR (2000) Serum tocopherols, selenium and lung cancer risk among tin miners in China. Cancer Causes and Control 11, 129-135.

Rayman MP (1997) Dietary selenium: time to act. British Medical Journal 314, 387-388.

Rayman MP (2000) The importance of selenium to human health. Lancet 356, 233-241. 
Rayman MP \& Clark LC (2000) Selenium in cancer prevention. In Trace Elements in Man and Animals-10: Proceedings of the Tenth International Symposium on Trace elements in Man and Animals, pp. 575-580 [AM Roussel, A Favier and RA Anderson, editors]. New York: Plenum Press.

Reilly C (1996a) Selenium in Food and Health, pp. 118-127. London: Blackie Academic and Professional.

Reilly C (1996b) Selenium in Food and Health, pp. 134-135. London: Blackie Academic and Professional.

Reilly C (1996c) Selenium in Food and Health, pp. 25-27. London: Blackie Academic and Professional.

Salonen JT, Alfthan G, Pikkarainen J, Huttunen JK \& Puska P (1982) Association between cardiovascular death and myocardial infarction and serum selenium in a matched pair longitudinal study. Lancet ii, July 24, 175-179.

Salonen JT, Salonen R, Seppaenen K, Kantola M, Parviainen M, Alfthan G, Maenpaa PH, Taskinen E \& Rauramaa R (1988) Relationship of serum selenium and antioxidants to plasma lipoproteins, platelet aggregability and prevalent ischemic heart disease in Eastern Finnish men. Atherosclerosis 70, 155-165.

Salvini S, Hennekens CH, Morris JS, Willett WC \& Stampfer MJ (1995) Plasma levels of the antioxidant selenium and risk of myocardial infarction among US physicians. American Journal of Cardiology 76, 1218-1221.

Sanders DE (1984) Use of selenium in problem cattle herds. Modern Veterinary Practice 65, 136-138.

Sappey C, Legrand-Poels S, Best-Belpomme M, Favier A, Rentier B \& Piette J (1994) Stimulation of glutathione peroxidase activity decreases HIV Type 1 activation after oxidative stress. Journal of AIDS Research and Human Retrovirology 10, 1451-1461.

Sattler W, Maiorino M \& Stocker R (1994) Reduction of HDL- and LDL-associated cholesterylester and phospholipid hydroperoxides by phospholipid hydroperoxide glutathione peroxidase and Ebselen (PZ 51). Archives of Biochemistry and Biophysics 309, 224-221.

Scott R \& MacPherson A (1998) Selenium supplementation in sub-fertile human males. British Journal of Urology 82, 76-80.

Shaheen SO, Sterne JAC, Thompson RL, Songhurst CE, Margetts BM \& Burney PGJ (2001) Dietary antioxidants and asthma in adults. American Journal of Respiratory and Critical Care Medicine 164, 1823-1828.

Shaw R, Woodman K, Crane J, Moyes C, Kennedy J \& Pearce N (1994) Risk factors for asthma symptoms in Kawerau children. New Zealand Journal of Medicine 107, 387--391.

Shisler JL, Senkevich TG, Berry MJ \& Moss B (1998) Ultravioletinduced cell death blocked by a selenoprotein from a human dermotropic pox virus, Science 279, 102-105.

Shortt CT, Duthie GG, Robertson JD, Morrice PC, Nicol F \& Arthur JR (1997) Selenium status of a group of Scottish adults, European Journal of Clinical Nutrition 51, 400-404.

Sinha R \& Medina D (1997) Inhibition of cdk2 kinase activity by methylselenocysteine in synchronised mouse mammary epithelial tumor cells. Carcinogenesis 18, 1541-1547.

Spallholz JE, Boylan LM \& Larsen HS (1990) Advances in understanding selenium's role in the immune system. Annals of the New York Academy of Sciences 587, 123-139.

Stadtman TC (1996) Selenocysteine. Annual Review of Biochemistry 65, 83-100.

Stryer L (1995) Biochemistry, 4th ed., p. 23. New York: Freeman and $\mathrm{Co}$.

Stuart LD \& Oehme FW (1982) Environmental factors in bovine and porcine abortion. Veterinary and Human Toxicology 24, 435-441.

Suadicani P, Hein HO \& Gyntelberg F (1992) Serum selenium concentration and risk of ischemic heart disease in a prospective cohort study of 3000 males. Atherosclerosis 96, 33-42.
Sunde RA (1997) Selenium. In Handbook of Nutritionally Essential Mineral Elements, pp. 493-556 [BL O'Dell and RA Sunde, editors]. New York: Marcel Dekker Inc.

Surai PF, MacPherson A, Speake BK \& Sparks NHC (2000) Designer egg evaluation in a controlled trial. European Journal of Clinical Nutrition 54, 298-305.

Taylor EW \& Nadimpalli RG (1999) Chemoprotective mechanisms of selenium in cancer and AIDS: evidence for the involvement of novel selenoprotein genes. InFo Onkologi Suppl. 2, 7-11.

Taylor PR \& Albanes D (1998) Selenium, vitamin E and prostate cancer - ready for prime time? Journal of the National Cancer Institute 90, 1184-1185.

Thomson CD, Robinson MF, Butler JA \& Whanger PD (1993) Long-term supplementation with selenate and selenomethionine: selenium and glutathione peroxidase ( $E C$ 1.11.1.9) in blood components of New Zealand women. British Journal of Nutrition 69, 577-588.

Turner RJ \& Finch JM (1991) Selenium and the immune response. Proceedings of the Nutrition Society 50, 275-285.

Underwood EJ (1977) Trace Elements in Human and Animal Nutrition, 4th ed., pp. 305-345. New York: Academic Press.

Ursini F, Heim S, Kiess M, Maiorino M, Roveri A, Wissing J \& Flohe L (1999) Dual function of the selenoprotein PHGPx during sperm maturation. Science 285, 1393-1396.

Vanderpas JB, Contempré B, Duale NL, Goossens W, Bebe N, Thorpe R, Ntambue K, Dumont J, Thilly CH \& Diplock AT (1990) Iodine and selenium deficiency associated with cretinism in Northern Zaire. American Journal of Clinical Nutrition $\mathbf{5 2}$, 1087-1093.

Virtamo J, Valkiela E, Alfthan G, Punsar S, Huttunen JK \& Karvonen MJ (1985) Serum selenium and the risk of coronary heart disease and stroke. American Journal of Epidemiology 122, 276-282.

Weber GF, Maertens P, Meng X \& Pippenger CE (1991) Glutathione peroxidase deficiency and childhood seizures. Lancet 337, 1443-1444.

Whanger P, Vendeland S, Park Y-C \& Xia Y (1996) Metabolism of sub-toxic levels of selenium in animals and humans. Annals of Clinical Laboratory Science 26, 99-113.

Wingler K, Bocher M, Flohe L, Kollmus H \& Brigelius-Flohe R (1999) mRNA stability and selenocysteine insertion sequence efficiency rank gastrointestinal glutathione peroxidase high in the hierarchy of selenoproteins. European Journal of Biochemistry 259, 149-157.

Wingler K, Muller C, Schmeh1 K, Florian S \& Brigelius-Flohe R (2000) Gastrointestinal glutathione peroxidase prevents transport of lipid hydroperoxides in $\mathrm{CaCo}-2$ cells. Gastroenterology 119 , $420-430$.

Wu SH, Oldfield JE, Whanger PD \& Weswig PH (1973) Effect of selenium, vitamin $\mathrm{E}$ and antioxidants on testicular function in rats. Biology of Reproduction 8, 625-629.

Yoshizawa K, Willett WC, Morris SJ, Stampfer MJ, Spiegelman D, Rimm EB \& Giovanucci E (1998) Study of prediagnostic selenium levels in toenails and the risk of advanced prostate cancer. Journal of the National Cancer Institute 90, 1219-1224.

Yu M-W, Horng I-S, Chiang Y-C, Liaw Y-F \& Chen C-J (1999) Plasma selenium levels and the risk of hepatocellular carcinoma among men with chronic hepatitis virus infection. American Journal of Epidemiology 150, 367-374.

Yu SY, Zhu YJ \& Li WG (1997) Protective role of selenium against hepatitis B virus and primary liver cancer in Qidong. Biological Trace Element Research 56, 117-124.

Zhang W, Ramanathan CS, Nadimpalli RG, Bhat AA, Cox AG \& Taylor EW (1999) Selenium-dependent glutathione peroxidase modules encoded by RNA viruses. Biological Trace Element Research 70, 97-116. 